\title{
DIFFUSE FLOW SEPARATION WITHIN KARST UNDERGROUND RIVER AT NGRENENG CAVE
}

\author{
By: \\ Tjahyo Nugroho Adji ${ }^{1}$, Heru Hendrayana ${ }^{2}$, Sudarmadji ${ }^{3}$, Suratman Woro ${ }^{4}$
}

\begin{abstract}
Diffuse flow is a dependable flow to recharge karst underground river within the dry season. This research is conducted at Ngreneng Cave, which is famous as the leakage tributary of Bribin River, the most important underground river in Gunungsewu karst area, Central Java. The objective of this research is to separate the karst flow components at Ngreneng Cave, in order to acknowledge the percentage of diffuse flow during the period of measurement. A water level data logger is installed during one year period to understand the variation of water level within dry and wet season. Furthermore, to define Stage Discharge Rating Curve, several discharge measurement is conducted within minimum, average and maximum discharge condition. Afterwards, the diffuse flow separation from its total flow is conducted by using automated base flow separation by digital filtering. The digital filtering values is acquired from the analysis of recession constant value in the occurrence of flood events in a year observation and related to the value of the base flow maximum indices (BFI) of karst aquifer. The result shows that during one year observation, Ngreneng Cave experiences 68 times of flooding, with digital filtering value of 0.992 . In general, the monthly estimation of the diffuse flow percentage is very close to $80 \%$, whereas it decreases to $41-59 \%$ during flood events.
\end{abstract}

Keywords: diffuse flow separation, Ngreneng cave, digital filtering.

\section{INTRODUCTION}

As an area which is dominated by secondary hydraulic conductivity, the groundwater concentration within karst aquifer located within underground river as a main drainage of water storage from the epikarst zone closed to the karst surface. White (1988), Ford and Williams (1992), Hobbs and Smart (1986), and Gillieson (1996) principally divide the flow within the karst aquifer into three components; specifically conduit, fissure and diffuse flow. M eanwhile, Domenico and Schwartz (1990), separates the flow component in the karst aquifer into two components; diffuse and conduit flow. Next, diffuse flow is recharged by percolation-water stored in the surface of karst hill (Haryono, 2001), and fills the karst underground river as a drip and fissure water through the cave ornaments. According to White (1993), diffuse flow is laminar and its characteristics follow the Darcy's Law. Diffuse flow then uniformly moves down through available joints, which is later called as baseflow, and supplies to underground river in the dry season when conduit and fissure flow have not already subsisted (Haryono and Adji, 2004). Conversely, conduit flow dominates the underground river within flood period while its response towards the rain events resembles to the surface river as point recharge. The nature of conduit flow is turbulent and the Darcy's Law is not applicable (Jankowski, 2001; Adji, 2005)).

This research is conducted within Ngreneng Underground River, which is located in Gunungsewu conical karst area. "Gunungsewu" karst type is firstly presented by Lehmann (1936),

\footnotetext{
${ }^{1}$ Faculty of Geography, Gadjah Mada University, Jogjakarta, Indonesia

${ }^{2}$ Department of Engineering Geology, Gadjah Mada University, Jogjakarta, Indonesia

${ }^{3}$ Faculty of Geography, Gadjah Mada University, Jogjakarta, Indonesia

${ }^{4}$ Faculty of Geography, Gadjah Mada University, Jogjakarta, Indonesia
} 
and recent discussion is published by Haryono and Day (2004). In addition, the Gunungsewu major underground river is Bribin River (Adji and Haryono, 2009; Adji et al, 1999), which is known as the most principal water supply in this area. This research aims to calculate baseflow percentage in Ngreneng Cave as the leakage of Bribin River tributary. Baseflow separation is conducted to define the percentage of the flow component which supplies the underground river and maintained by the water components discharge from the karst aquifer. There are two karst flow components which are separated: (1) direct (conduit) and intermediate (fissure) flow; and (2) diffuse flow (baseflow). In addition, due to the length of the discharge data recorded (per 30 minutes) during one year, the diffuse flow separation is carried out by using an Automated Base Flow Separation by Digital Filtering method, which is developed by Eckhardt (2005). This method requires data of recession constant.

\section{METHOD}

A water level data logger was set during one year period from May, $1^{\text {st }} 2006$ to April, $30^{\text {th }}$ 2007 with a recording interval of 30 minutes. Furthermore, discharge measurement within minimum, average, and maximum water level condition is conducted to define Stage Discharge Rating Curve, so that the discharge fluctuation during one year is defined. Next, several flood events is chosen to calculate the recession constant value within Ngreneng Underground River, with the equation of:

$$
Q(t)=Q\left(t_{o}\right) e^{-k\left(t-t_{o}\right)}
$$

Where $\mathrm{k}$ is the recession constant within river flow, $\mathrm{Q}(\mathrm{t})$ is the discharge at a later time $\mathrm{t}$, and $\mathrm{Q}\left(\mathrm{t}_{0}\right)$ is the discharge at the initial discharge- $\mathrm{t}=0$ (Schulz, 1976). Then, if this formula is applied in semi log scale, it is supposed to be linier, therefore:

$$
\begin{aligned}
& \ln Q(t)=-k\left(t-t_{o}\right)+\ln Q\left(t_{o}\right) \\
& k=-1 / t-t_{o} \ln \left(Q_{t} / Q_{o}\right)
\end{aligned}
$$

The baseflow separation analysis and the calculation of the direct flow along the year are conducted by using Automated Baseflow Separation by Digital Filtering Method (Eckhardt, 2005). This method is to find digital filtering value of river flow based on baseflow recession constant value of one year discharge hydrograph. Also, the separation is related to the maximum base flow indices value $\left(\mathrm{BFI}_{\max }\right)$ in the karst aquifer, the equation is:

$$
q_{b(i)}=\frac{\left(1-B F I_{\max }\right) a q_{b(i-1)}+(1-a) B F I_{\max } q_{i}}{1-a B F I_{\max }}
$$

Where $q_{b(i)}$ is the baseflow at time step $i, q_{b(i-1)}$ is the baseflow at the previous time step i- $1, q_{i}$ is the stream flow at time step $\mathrm{i}$, $\mathrm{a}$ is the recession constant and $\mathrm{BFI}_{\max }$ is the maximum value of the baseflow index that can be measured. Meanwhile, the value of $\mathrm{BFI}_{\max }$ value used is 0.8 , according to 
the nature of the karst aquifer which is porous and the continuous discharge along the year (Eckhardt, 2005).

\section{RESULT}

The situation and the water level data logger set on Ngreneng Cave is shown in Figure 1. The discharge measurement during a year is conducted in a certain time to represent several water level conditions within underground river. The result of discharge measurement is shown in Table 1.
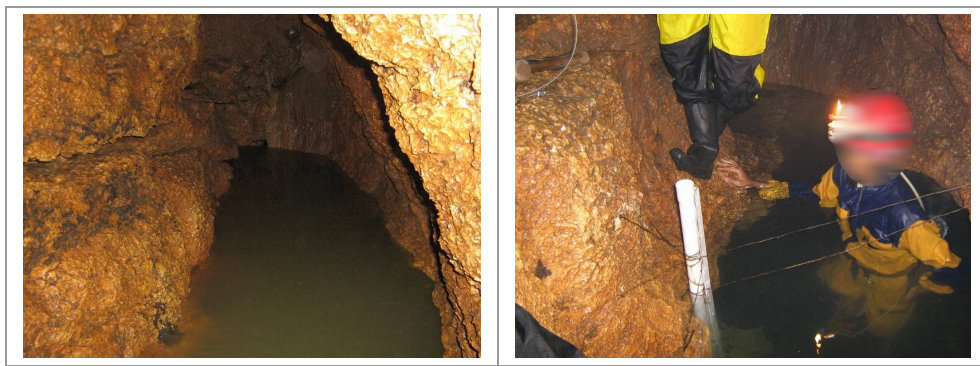

Figure 1. Ngreneng Cave River (left), and water level data logger installation (right)

Table 1. Ngreneng Cave discharge measurement in various water level condition

\begin{tabular}{|r|r|r|}
\hline Date & Water level $(\mathrm{m})$ & \multicolumn{1}{c|}{ Discharge (It/sec) } \\
\hline $20 / 4 / 06$ & 1.80 & 545.96 \\
\hline $26 / 4 / 06$ & 1.61 & 488.33 \\
\hline $22 / 5 / 06$ & 1.21 & 283.11 \\
\hline $22 / 6 / 06$ & 1.17 & 263.61 \\
\hline $19 / 7 / 06$ & 0.97 & 219.00 \\
\hline $23 / 8 / 06$ & 0.71 & 140.71 \\
\hline $20 / 9 / 06$ & 0.62 & 123.57 \\
\hline $15 / 11 / 06$ & 0.38 & 75.73 \\
\hline $20 / 12 / 06$ & 0.43 & 100.61 \\
\hline
\end{tabular}

Source: Field measurement (2006)

Furthermore, regression analysis is applied to define the stage discharge rating curve of Ngreneng Cave as presented in Figure 2. With the equation in rating curve, the discharge calculation in the future can be rapidly solved just by looking at the water level stage close to the water level data logger. The equation of the rating curve is:

$y=322.18 x-92.932$

where, $y$ is the discharge $(\mathrm{It} / \mathrm{sec})$ and $\mathrm{x}$ is the water level $(\mathrm{m})$. 


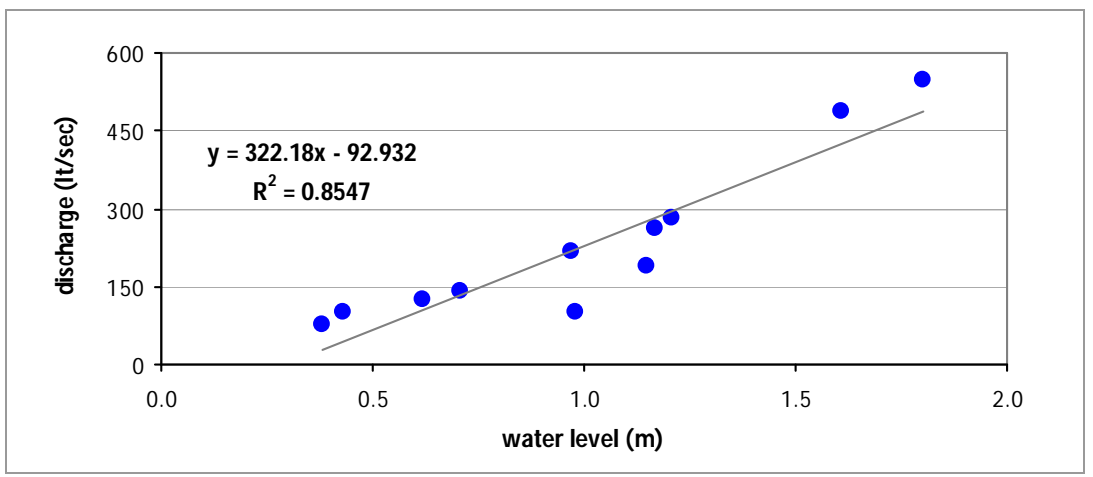

Figure 2. Stage discharge rating curve in Ngreneng Cave

The equation is then used to calculate the Ngreneng River discharge during a year with the time interval of water level recording once in 30 minutes, as shown in Figure 3.

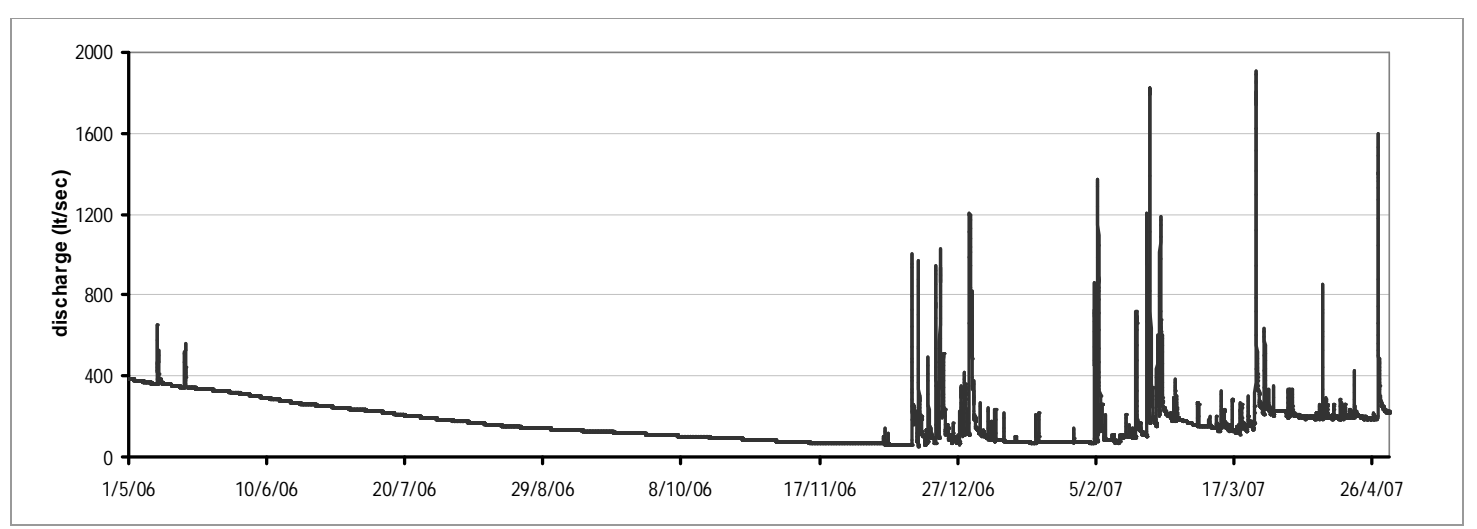

Figure 3. One-year discharge fluctuation in Ngreneng Cave (1 M ay 2006-31 M arch 2007)

According to the discharge hydrograph at Ngreneng Cave, from 68 times flooding to occur, 8 flooding are selected which fit to the requirements of its recession constant to be calculated (presented in Table 2.) From this table, the average value of diffuse flow recession constant is 0.992 .

Table 2. Selected Flood Recession Constant in Ngreneng Cave

\begin{tabular}{|c|c|c|c|c|}
\hline \multirow{2}{*}{ No } & \multicolumn{2}{|c|}{ Waktu } & \multirow{2}{*}{$\begin{array}{l}\text { Peak discharge } \\
\text { (It/sec) }\end{array}$} & \multirow{2}{*}{$\begin{array}{c}\text { Diffuse flow } \\
\text { recession constant } \\
\left(K_{b}\right)\end{array}$} \\
\hline & Date & Time & & \\
\hline 1 & $13 / 12 / 06$ & $19: 30$ & 1005,2 & 0,9991 \\
\hline 2 & $15 / 12 / 06$ & $18: 30$ & 882,1 & 0,9881 \\
\hline 3 & $18 / 12 / 06$ & 13:30 & 454,6 & 0,9933 \\
\hline 4 & $20 / 12 / 06$ & $18: 30$ & 947,5 & 0,9900 \\
\hline 5 & $22 / 12 / 06$ & $20: 30$ & 514,2 & 0,9985 \\
\hline 6 & $5 / 2 / 07$ & $17: 00$ & 1373,0 & 0,9910 \\
\hline 7 & $19 / 2 / 07$ & $20: 30$ & 890,2 & 0,9779 \\
\hline 8 & $20 / 2 / 07$ & $20: 00$ & 1788,9 & 0,9968 \\
\hline
\end{tabular}

In general, Nathan and M cMahon (1990) explain that the range value of recession constant for the baseflow $\left(\mathrm{K}_{\mathrm{b}}\right)$ is between 0.93-0.995. According to the recession constant calculation (Table 2 ), the value of the baseflow recession $\left(K_{b}\right)$ ranges between 0.977-0.999 with an average of 0.992 . 
Then, after being separated by digital filtering method (Figure 4), the monthly percentage of diffuse flow from the total discharge is presented in Table 3.

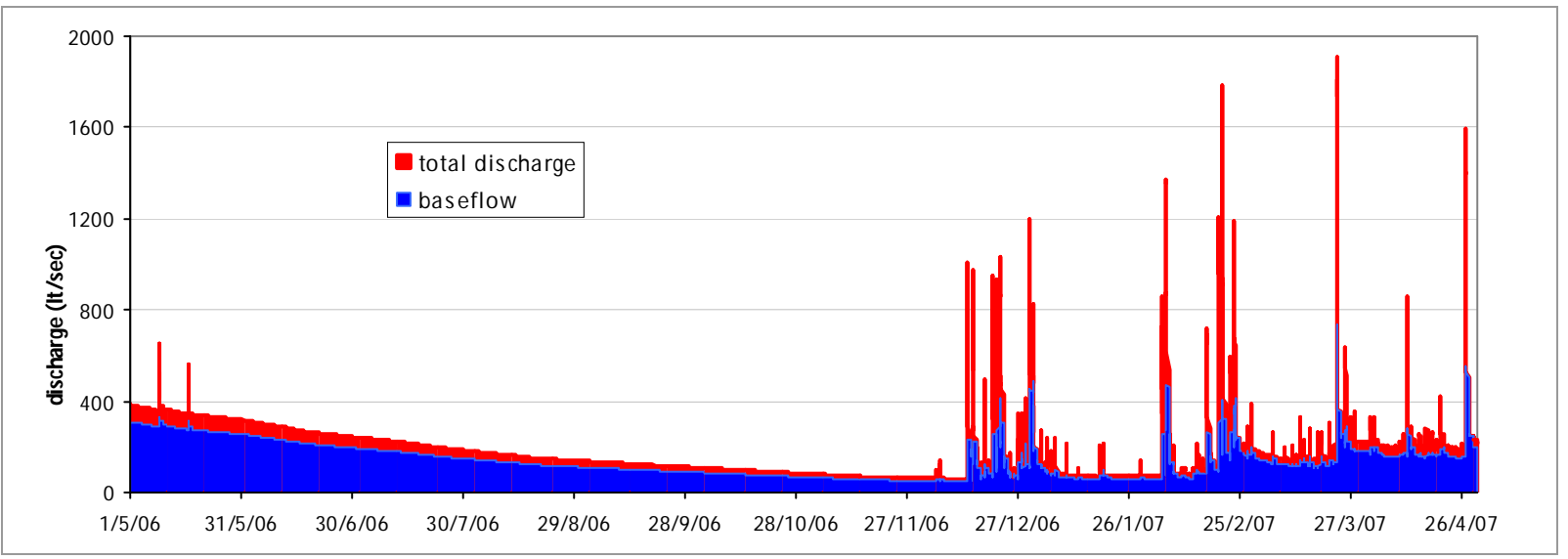

Gambar 4. Diffuse flow separation using digital filtering method in Ngreneng Cave (1 May 2006-31 March 2007)

Table. 3. M onthly diffuse flow percentage in Ngreneng Cave

\begin{tabular}{|c|l|c|c|}
\hline No & \multicolumn{1}{|c|}{ Month } & (\%) & Season \\
\hline 1 & May 2006 & 80.35 & dry \\
\hline 2 & June 2006 & 80.36 & dry \\
\hline 3 & July 2006 & 80.37 & dry \\
\hline 4 & August 2006 & 80.38 & dry \\
\hline 5 & September 2006 & 80.38 & dry \\
\hline 6 & October 2006 & 80.38 & dry \\
\hline 7 & November 2006 & 80.38 & dry \\
\hline 8 & December 2007 & 81.78 & wet \\
\hline 9 & January 2007 & 82.93 & wet \\
\hline 10 & February 2007 & 83.48 & wet \\
\hline 11 & Machr 2007 & 82.41 & wet \\
\hline 12 & April 2007 & 81.78 & wet \\
\hline
\end{tabular}

Source: data analysis 2007

According to the calculation monthly percentage of diffuse flow (Table 3), it generally appears that the percentage close to $80 \%$. It is reasonable since the nature of karst aquifer flow is perennial with high porosity. By looking at the monthly percentage, it can be concluded that the propensity of Ngreneng flow characteristics is dominated by the diffuse flow. In addition, the percentage of diffuse flow increases during wet season to around $82-83 \%$. The beginning of the wet season on December 2006 doesn't cause the percentage of the base flow to decrease, as it happen at the other caves around Ngreneng Cave (Adji, 2008), but it shows increasing percentage by around 1$2 \%$. M eanwhile, its percentage decrease sharply within flood events (Table 4). 
Table. 4. Diffuse flow percentage within selected flood events in Ngreneng Cave

\begin{tabular}{|r|r|r|r|c|}
\hline No & \multicolumn{1}{c|}{ Date } & Time & Peak discharge (It/ sec) & $\%$ \\
\hline 1 & $13 / 12 / 06$ & $19: 30$ & 1005,2 & 41,43 \\
\hline 2 & $15 / 12 / 06$ & $18: 30$ & 882,1 & 44,68 \\
\hline 3 & $18 / 12 / 06$ & $13: 30$ & 454,6 & 50,85 \\
\hline 4 & $20 / 12 / 06$ & $18: 30$ & 947,5 & 43,88 \\
\hline 5 & $22 / 12 / 06$ & $20: 30$ & 514,2 & 44,68 \\
\hline 6 & $5 / 2 / 07$ & $17: 00$ & 1373,0 & 45,68 \\
\hline 7 & $19 / 2 / 07$ & $20: 30$ & 890,2 & 40,79 \\
\hline 8 & $20 / 2 / 07$ & $20: 00$ & 1788,9 & 59,77 \\
\hline
\end{tabular}

\section{DISCUSSION}

The diffuse flow percentage within flood events shows very different percentage from its monthly percentage. At the early wet season, the percentage is always under 50\% (41-50 \%); even it shows the least percentage $(41.43 \%)$ in the first flooding to occur in 13 December 2006. This fact indicates that karst aquifer hasn't been already recharged diffuse flow component yet to the river, as the first flood input enormous component of conduit flow. Next, the diffuse flow within flood events gradually increases with the maximum percentage to achieve at 20 February 2007 by $59.77 \%$.

Another interesting fact is found when the diffuse flow percentage increases during the wet season. This increasing trend is due to the effect of enormous direct flow enters the cave as morphology of Ngreneng Cave functions as a sinkhole of some karst basins. In addition, conduit flow dominates in very short time, shows by value of $K_{c}$ and $T_{b}$ small (Adji, 2008). Accordingly, it appears that the monthly average diffuse flow percentage is greater compared to its dry season monthly percentage. On the contrary, within flood events, the percentage decreases dramatically because the recharges of conduit flow to occur.

\section{REFERENCES}

Adji, T.N. dan Haryono, E., 1999. Konflik Antara Pemanfaatan Batugamping dan Konservasi Sumberdaya Air Das Bribin di Wilayah Karst Gunung Sewu, Makalah Lokakarya Nasional M enuju Pengelolaan Sumberdaya Wilayah Berbasis Ekosistem Untuk Mereduksi Konflik Antar Daerah, Yogjakarta, , Fakultas Geografi, Universitas Gadjah Mada, September 1999

Adji, T.N., 2005, Agresivitas Airtanah Karst Sungai Bawah Tanah Bribin, Gunung Sewu, Indonesian Cave and Karst Journal, Vol. 1 No1, HIKESPI

Adji, T.N., Haryono, E., Woro, S, 1999, Kawasan Karst dan Prospek Pengembangannya di Indonesia, Seminar PIT IGI di Universitas Indonesia, 26-27 Oktober 1999

Adji, T.N., 2008. Pemisahan Aliran Dasar Sungai Bawah Tanah Karst di Gua Gilap, Proceeding of Indonesian Scientific Karst Forum (ISKF\#1), 19-20 Aug 2008, Jogjakarta,Indonesia 
Eckhardt, K, 2005. How to construct recursive digital filters for baseflow separation. Hydrological Processes 19, 507-515.

Ford, D. ,Williams, P. 1992. Karst Geomorphology and Hydrology, Chapman and Hall, London

Gillieson, D., 1996, Caves: Processes, Development, and M anagement, Blackwell, Oxford

Haryono, E. dan Adji, T.N. 2004. Geomorfologi dan Hidrologi Karst. Yogyakarta: Kelompok Studi Karst, Fakultas Geografi, Universitas Gadjah Mada

Haryono, E., 2001. Nilai Hidrologis Bukit Karst, Makalah pada seminar Nasional, Eko-Hidrolik, 28-29 Maret 2001, Jurusan Teknik Sipil , UGM

Haryono, E., Day, M. , 2004. Landform differentiation within the Gunung Kidul Kegel karst, java, Indonesia, Journal of Cave and Karst Studies, 66-August

Hobbs, S.L. ,Smart, P.L., 1986. Characteristics of Carbonate Aquifers: A conceptual basis. In Proceedings of environmental Problem in Karst Terrains and Their Solution. Bowling Green, KY: National Well Water Association, 1-4

Jankowski, J., 2001. Groundwater Environment, Short Course Note, School of Geology, University of New South Wales, Sydney, Australia

Lehmann, H., 1936. M orfologiche Studien auf Java, Gohr, Abh, 3, Stutgart

Nathan R.J., Mcmahon, T.A., 1990. Evaluation of automated techniques for baseflow and recession analysis. Water Resources Research. 26(7):1465-1473.

Schulz, E.F., 1976. Problems in Applied Hydrology. Water Resources Publication, Colorado

White, W.B., 1988. Geomorphology and Hydrology of Karst Terrain. Oxford University Press, New York

White, W.B., 1993. Analysis of Karst Aquifer. In:Alley, W.M. (editor), Regional Groundwater Quality. Van Nostrand Reinhold, New York 